\title{
Augustinci pustinjaci riječkog sv. Jeronima u 15. stoljeću
}

\begin{abstract}
Riječku crkvu sv. Jeronima sa samostanom izgradili su augustinci pustinjaci svetog Augustina (Ordo eremitarum sancti Augustini). Iako se radi o prvoj redovničkoj zajednici u gradu Rijeci, njihova prošlost nije do sada u dovoljnoj mjeri istražena. Od 14. stoljeća do ukidanja samostana 1788. godine, obilježili su grad i širu okolicu u vjerskom, kulturnom i ekonomskom pogledu. Na temelju sačuvanih izvora u Hrvatskoj i inozemstvu autor donosi do sada u velikoj mjeri nepoznate podatke o životu riječkih augustinaca pustinjaka u 15. stoljeću. Rad prenosi vijesti o raznim samostanskim dobrima stečenim tijekom 15. stoljeća, posebno ističući povelju Reinprechta Walseeovca iz 1429. Važan način stjecanja dobara bile su i misne zaklade. Najznačajniji podatak odnosi se na uspostavu hospitala na riječkoj Andrejšćici u 15. stoljeću, za koji se do sada nije znalo. Donose se i podaci o značajnim redovnicima toga razdoblja.
\end{abstract}

\section{Uvod}

Iako je sv. Augustina (354-430) smatrao svojim idejnim začetnikom, Red augustinaca pustinjaka (Ordo eremitarum sancti Augustini) nastao je tek u 13. stoljeću ujedinjenjem više pustinjačkih skupina s Apeninskog poluotoka. Historiografija augustinskoga reda danas se ne poziva na izravan kontinuitet između monaha $\mathrm{s}$ konca 4. stoljeća u sjevernoj Africi kojima je sveti Augustin dao pravilo i onih pustinjaka čijim je ujedinjenjem u 13. stoljeću uspostavljen augustinski red. ${ }^{1} \mathrm{U}$ 16. stoljeću augustinci će biti pribrojeni prosjačkim redovima Katoličke crkve (uz franjevce, dominikance i karmelićane). Današnje je službeno ime te redovničke zajednice Red sv. Augustina (Ordo sancti Augustini).

Povijest augustinaca pustinjaka u hrvatskoj je historiografiji vrlo malo poznata, iako je njihova prisutnost, osobito u predosmanskom razdoblju, izrazita diljem Hrvatske. ${ }^{2}$ Augustinci su najstarija redovnička zajednica u Rijeci. Bez obzira na to

GROSSI, MARÍN I CIOLINI 1993: 187.

2 Točan niz augustinskih samostana u Hrvatskoj nije do kraja definiran. Osim Rijeke i Istre, najčešće se spominju: Ilok, Vinkovci, Vukovar, Osijek, Borovo, Velika, Garić, Komar, Hvar, Brač, Brinje itd. DOBRONIĆ 1987: 1-25; ISTA 1996: 57-63; BATELJA 2007; MARDEŠIĆ 2005: 7-8; MEDVED 2015-2016: 443-452; ZANINOVIĆ RUMORA 1997: 172-184. 
što su obilježili četiri stoljeća povijesti grada, može se reći kako im historiografi nisu pristupali s dužnom pozornošću. ${ }^{3}$ Do zatvaranja samostana dolazi 1788. u okviru jozefinističkih reformi crkvenih struktura Josipa II. ${ }^{4}$ Uslijedilo je raspršivanje i djelomično uništenje arhivske građe augustinskog samostana, a to je, uz činjenicu da se više nikad nisu vratili u Hrvatsku, uzrokovalo zanemarivanje povijesti augustinskih redovnika Rijeke. ${ }^{5}$

\section{Opće okolnosti života augustinaca u Rijeci 15. stoljeća}

Počeci augustinske prisutnosti u Rijeci vezani su uz gospodare grada, Devince i Walseeovce. Umjesto do sada najčešće spominjane 1315. kao godine podizanja crkve i samostana, uvidom u temeljne autore augustinskoga reda i mahom neistražena arhivska vrela, kao i u genealogiju utemeljitelja Walseeovaca, njihov dolazak valja posticipirati za pedesetak godina, smještajući dataciju u razdoblje od 1368. do 1408./1409. ${ }^{6}$

Za riječke augustince 15 . stoljeće znači vrijeme učvršćenja zajednice, nakon što je 1408./1409. dovršen samostanski kompleks s crkvom sv. Jeronima. To prvo razdoblje njihova djelovanja završava pogoršanjem situacije početkom 16. stoljeća rastom napetosti između Venecije i Austrije. Uslijedit će mletačko zauzeće i pljačka grada 1509. koji su uzrokovali znatno uništenje samostana. Zbog toga redovnici moraju napustiti svoje obitavalište sve do 1514 . godine. ${ }^{7}$

Riječki samostan tijekom 15. stoljeća pripada velikoj Bavarskoj augustinskoj provinciji, unutar distrikta za područje Štajerske i Koruške. Taj će se distrikt, pod riječkim vodstvom, osamostaliti u drugoj polovini 16. stoljeća, a od konca 17. stoljeća do ukidanja samostana 1788. pripadat će Austrijskoj provinciji.

S Walseeovcima se u Rijeci 15. stoljeća događa veliki zamah trgovine koji nadilazi okvire uskog riječkog područja. Ovdje se odvija razmjena dobara između hrvatskog i slovenskog zaleđa, kao i šireg pojasa istočne jadranske obale, s Apeninskim poluotokom. Riječ je o željezu, koži, drvu, vosku, medu, soli, žitu, vinu i sl. ${ }^{8}$ Ekonomski razvoj značio je i jačanje materijalnog položaja augustinaca, tada jedinih redovnika u gradu.

3 U posljednje vrijeme iznova se rađa interes prema prošlosti ovoga samostana: BATELJA 2008; BRADANOVIĆ 2017; KOSANOVIĆ 2018: 23-33; MEDVED 2015-2016: 443-452; ISTI 2018: 9-21.

4 KOBLER 1896: 98-105; TORCOLETTI 1944; HERLJEVIĆ 1967-1969: 435-459; GIGANTE 1910: 16-96; DEPOLI 1912: 131-133; MATEJČIĆ 1988: 45-49; BATELJA 2006: 31-43.

5 Vidi članak Marka Medveda ,'Incuria et vandalismus' - sudbina arhiva augustinskog samostana sv. Jeronima u Rijeci“" u postupku objavljivanja u časopisu Arhivski vjesnik.

6 ROSNAK I SCHIER 1776: 29. Usp. KUNZELMANN 1972: 20; BRADANOVIĆ 2018: 116.

7 Prior Ivan Primožić, u desetljećima nakon povratka redovnika, obnovit će samostan i crkvu.

8 KLEN 1998: 84-85. 


\section{Materijalna osnova riječkog augustinskog samostana:} dotacija, misne zaklade, ugovori

\section{Reinprecht Walseeovac potvrđuje 1429. dotaciju riječkim augustincima}

Nestankom muške loze Devinaca, 1399. nasljeđuju ih Walseeovci. Uz Rijeku, oni vladaju Kastvom, Mošćenicama i Veprincem. Riječki augustinci svojim utemeljiteljima smatraju kako Devince tako i Walseeovce. Naime, Reinprecht Walsee potvrdio je listinom iz 1429. dobra koja je Hugon Devinski, njegov djed po majčinoj liniji, udijelio augustincima sv. Jeronima. U nedostatku povelje utemeljenja iz 14. stoljeća, na ovu se povelju pozivala redovnička zajednica kada je trebalo braniti dobra, ali i historiografija u pitanjima datiranja augustinskih početaka u Rijeci. ${ }^{9}$

U diplomi izdanoj uoči sv. Jurja $1429 .{ }^{10} \mathrm{u}$ Devinu, Reinprecht tvrdi da je njegov predak Hugo Devinski samostan i crkvu sv. Jeronima iznova podignuo, izgradio i obdario dobrima (de novo edificavit, construxit et dotavit). Reinprecht udovoljava molbi samostanske zajednice, predvođene priorom Ivanom iz Reichenburga, koja je tvrdila da nema utemeljiteljskih isprava samostana osnovanog od njegova pretka, zbog čega traži da im se ispravama i pečatima potvrde dobra dobivena od Hugona Devinca. Proglašujući se vjernim skrbnikom i zaštitnikom riječkog samostana od svakoga nasilja i sramote koji bi im mogli biti naneseni, među dotacijom samostana Walseeovac nabraja dobra u riječkoj okolici i širem zaleđu: crkvu sv. Martina na granici s Kastavštinom, s pripadajućim zemljištem, crkvu sv. Andrije pored grada s pripadajućim zemljištem, crkvu sv. Cecilije s pripadajućim zemljištem i crkvu sv. Nikole s pripadajućim zemljištem. Uz to, redovnicima je potvrđeno vlasništvo nad selom Lipa (koje povelja naziva Linda) i selom Studena, s dobrima koji im pripadaju. Priznaje im se pravo na desetinu usjeva, kozlića i pčela (dakle meda) iz slovenskih mjesta Podgraje, Žabiče, Kuteževo i Trpčane. K tome, potvrđuje im se četvrti dio desetine od vina, usjeva i kozlića u gradu Rijeci. ${ }^{11}$ Sve navedeno

\section{KOBLER I 1896: 94.}

10 21. travnja 1428.

11 U Sveučilišnoj knjižnici u Beču sačuvan je kartular riječkog augustinskog samostana Diplomatarium monasterii sancti Hieronimi ordinis eremitarum sancti Augustini in terra Fluminis sancti Viti (Diplomatarium) koji donosi prijepise Reinprechtove povelje na latinskom LXXXXIvLXXXXIIIr (94v-96r), talijanskom LXXXXVr-LXXXXVIIr (98r-100r) i hrvatskom jeziku na glagoljici LXXXXVIIIIr-CIr (102r-104r). Prijepise svih triju jezičnih verzija povelje i njezin prijevod donio je DEKOVIĆ 2003. On je jedini koji se koristio tim kartularom, obradivši samo glagoljske tekstove. Vidi: DEKOVIĆ 2006: 304-336. Kartular je zapisan u 16. stoljeću i donosi 89 ovjerenih prijepisa darovnica, povelja, oporuka i ugovora koji se odnose na 15. i 16. stoljeće. Österreichische Universitätsbibliothek, Wien (dalje: ÖUB), II 351.241. Kartular je, slijedeći definiciju Tomislava Galovića, povjesničara koji je obradio naš najpoznatiji Rogovski kartular (benediktinskog samostana sv. Ivana evanđelista u Biogradu), kopijalna knjiga destinatara, tj. 
čini jezgru vlasništva augustinskoga samostana koja utemeljuje položaj riječkih redovnika unutar feudalnoga društvenog sustava za naredna tri i pol stoljeća života. Stotinjak godina nakon toga, Ferdinand Habsburški potvrdio je 1528. spomenutu dotaciju, dodajući joj i misne zaklade stečene tijekom 15 . stoljeća. ${ }^{12}$

\section{Razna augustinska dobra iz 15. stoljeća}

Riječki augustinski samostan sv. Jeronima bio je važan feudalni čimbenik u gradu i okolici. Torcoletti piše kako su riječki augustinci ,prvi i najmoćniji gospodari u gradu“. ${ }^{13}$ Ta se njegova prosudba, valja precizirati, odnosi na vrijeme prije 17. stoljeća i dolaska Družbe Isusove. Dobra Andrejšćica i Cecilinovo (zapadno od gradskih zidina), Sv. Nikola (Krnjevo) i Sv. Martin (na granici riječkog distrikta s Kastavštinom), hrvatska sela Studena, Lipa i Lisac, slovenska sela Podgraje, Žabiče, Kuteževo i Trpčane, dijelovi mjesta Donji Zemon, Podstenje i Vrbovo čine osnovicu feudalnog položaja riječkog augustinskog samostana. Ta su dobra redovnici, uz već spomenutu Reinprechtovu povelju iz 1429., stekli upravo u 15. stoljeću. S godinama ta se dotacija znatno obogaćuje dobrima u gradu i okolici, najčešće uslijed pobožnih oporuka, od kojih su najvažnije one iz 15. stoljeća vezane uz kapetana M. Frayna, I. Čehovara i W. Walseea. ${ }^{14}$

Augustinci stječu mnogo dobara, unutar i izvan gradskih zidina, kuća (s okućnicom ili bez), obradivog i neobradivog zemljišta koje vrela nazivaju raznim nazivima - muralea, mirischium i sl. Do nekretnina su redovnici vrlo često dolazili na temelju oporuka riječkih građana koji su od augustinaca tražili molitvu za sebe i pripadnike vlastitih obitelji, kao i pravo na pokapanje u augustinskoj crkvi sv. Jeronima, unutar ili pored crkve sv. Andrije, odnosno misama zadušnicama na godišnjice smrti. Te su nekretnine redovnici potom davali u zakup, prodavali ili mijenjali za druga dobra, prava ili povlastice, ostvarujući tako zaradu. Sve to dovelo ih je do onog položaja koji Torcolettija opravdano navodi na tvrdnju o riječkim augustincima kao moćnim riječkim gospodarima.

Od ugovora iz 15. stoljeća istaknimo sljedeće. Prior augustinskog samostana Ivan 19. listopada 1418. daje u najam Petru Lambuthu iz Rijeke obrađena i neobrađena zemljišta crkve sv. Augustina na Cecilinovu i na Kozali. Vijest o tome

rukopisna knjiga u koju fizičke ili pravne osobe unose prijepise isprava izdanih u vlastitu korist. Vidi GALOVIĆ 2018: 14. Galović je dva kartulara riječkog augustinskog samostana (uz navedeni Diplomatarium i Transumpta privilegiorum fundationalium aliorumque instrumentorum documentorum memorabilium authentica conventus s. Hieronymi Fluminensis Ordinis eremitarum s. Augustini et abbatiae s. Iacobi a Palo) smjestio u opći presjek kartulara na hrvatskom prostoru. Usp. GALOVIĆ 2016: 92.

12 KOBLER I 1896: 94

13 TORCOLETTI 1944: 15.

14 Vidi podrobnije o tim misnim zakladama u nastavku. 
najmu zapisana je u samostanskom kartularu (Diplomatarium), a njezina se važnost očituje u tome što svjedoči da već tada postoji crkva sv. Augustina na današnjoj riječkoj Žabici, dobro koje će preuzeti kapucini $1610 .{ }^{15}$

Augustinci su u 15. stoljeću posjedovali kuću s peći u Kastvu. Naime, s Tomom, đakonom iz Kastva, sinom tkalca Blaža, dolazi do zamjene dobara na temelju ugovora od 31. svibnja 1474., prema kojem samostan spomenutoj osobi na korištenje tijekom života ustupa kuću s peći, koju augustinci posjeduju u Kastvu i koja ondje graniči s javnim putom, u zamjenu za kuću u Rijeci u vlasništvu oca spomenutog đakona, koja graniči s nasljednicima Andregedić, s kućom Jakova Bacchinija i onom Petra Jurića. ${ }^{16}$

Iz 1459. datira vijest zapisana u knjizi notara i kancelara de Muttine o tome da je augustinski prior Albert od suca Aleksandra Grobničana kupio mlin na Grohovu za 50 libara. ${ }^{17} \mathrm{~K}$ tome, riječki augustinci posjedovali su manji mlin na Cecilinovu (danas Mlaka) i veći mlin na Rječini. Veliki mlin riječkih augustinaca bio je na dvama kotačima s lopaticama i turnićem. Otočić na kojem je bio smješten zvao se u to vrijeme Otočac, kasnije Školjić. ${ }^{18}$ Augustinska vrela nazivaju to područje putom mlinova (agro fluminensi in contrata seu via molendinorum). ${ }^{19}$

Riječki augustinski samostan dobivao je i vino s otoka Krka jer je u Dubašnici i Baški posjedovao više vinograda. Najstarije vijesti o augustinskoj lozi u Dubašnici potječu iz 15. stoljeća. Dana 6. travnja 1495. Moiša Klaričić i supruga mu Dorka iz Dubašnice pišu augustinskom prioru sv. Jeronima dopis na glagoljici zahtijevajući da im se pošalje 10 dukata, iznos za koji su riječkim augustincima prodali zemlju. Traže da se iznos pošalje po Ivanu Lukačiću. Spis je napisao i ovjerio notar Petar u Dubašnici. ${ }^{20} \mathrm{U}$ spomenutom spisu navodi se kako dobro graniči s drugim augustinskim zemljištem, što govori o tome da su i prije toga riječki redovnici imali posjede u Dubašnici. S time je u vezi i spis koji prenosi Darko Deković o tome da su tri mjeseca nakon gore spomenutog akta određene točne granice zemljišta. Naime, 10. srpnja 1495. utvrđene su granice dobra u Dubašnici koje je Moiša Klaričić, u tome trenutku već pokojni, prodao riječkim

15 ÖUB, Diplomatarium, VIv-VIIv (9v-10v).

16 Državni arhiv u Rijeci (dalje: DARI), HR-DARI-250, kut. 2, pergamene, br. 8. Usp. DARI, HR-DARI-250, kut. 1, Protocollum conventus, N. 15, pag. 4; Usp. GIGANTE 1910: 17, 23-24, 44; HERLJEVIĆ 1967-1969: 450.

17 ZJAČIĆ 1955-1956: 391.

18 DEPOLI 1929: 75.

19 Povelju je ovjerio notar Oktavijan Cigollus, Tršćanin. DARI, HR-DARI-250, kut. 2, pergamene. Suprotno tome, HERLJEVIĆ 1967-1969: 452 piše da je Bachino samostanu prodao dobro. DARI, HR-DARI-250, kut. 1, Protocollum conventus, N. 80, pag. 18; ÖUB, Diplomatarium, XXXIIIv-XXXVv (36v-40v).

20 ŠURMIN 1898: 384. Usp. DEKOVIĆ 2011: 73. Taj je ugovor predmet interesa nekoliko radova. BOTICA I GALOVIĆ 2014: 55-71. 
augustincima. Njegova udovica, pred svjedocima Ivanom Lukačićem i Jakovom Prošćevićem iz Dubašnice, pokazala je granice zemljišta: ono sa zapada graniči $\mathrm{s}$ javnim putom, s istoka s nešto trsa, s južne s Dijanovom zemljom, a na sjeveru s onom augustinaca koja, pak, graniči s vinogradom (brajdama) Surčića i Kučića. Akt, napisan i potpisan od žakna Martina, potvrđuje da je gospođa Dorka isplaćena. ${ }^{21}$ Protocollum conventus Fluminensis Ordinis eremitarum s. patri Augustini ad s. Hieronymum, ${ }^{22}$ najvrednije samostansko vrelo sačuvano u Rijeci, ne prenosi podatak vezan za taj poslovni čin, ali donosi vijest da četiri godine poslije, 20. kolovoza 1499., zemljište (vrta, vinograda i obradive površine) biva darovano od Doroteje, udovice pok. Jakominija. Ta zemlja graniči s onom njezine djece Andrije i Katarine, pod uvjetom da joj riječki augustinci služe jednu misu godišnje. Smatramo da je navjerojatnije riječ o istoj osobi, iako ne možemo biti posve sigurni. ${ }^{23}$

\section{Neke misne zaklade augustinskog samostana iz 15. stoljeća}

Vlasništvo augustinaca nad dobrim dijelom zemljišta i dobara u bližoj i široj okolici Rijeke rezultat je, s jedne strane, dotacije feudalnih gospodara Devinaca i Walseeovaca i, s druge, pobožnih oporuka najčešće vezanih uz misne zaklade. Navedimo najvažnije zaklade iz 15 . stoljeća.

Riječki kapetan plemeniti Matija Frayn utemeljuje 28. siječnja 1435. zakladu na oltaru Triju Kraljeva za prvu svakodnevnu misu za sebe i svoje. Frayn (kojega Kobler naziva Rayn) bio je oženjen za sestru Jakova Raunachera, također riječkog kapetana. Tom je zakladom (čiji je prijepis 1521. učinio notar iz izvornika, a 1704. upisan je u Protocollum conventus), koja se najprije temeljila na 100 maraka, da bi potom bila izmijenjena za 5 hueba u Sloveniji (tri huebae u Donjem Zemonu, jednu u Podstenjama i jednu u Vrbovu), osnovan misni legat prve svakodnevne mise za kapetana Frayna i njegove na spomenutom oltaru augustinske crkve sv. Jeronima. ${ }^{24} \mathrm{U}$ odvojenom zapisu istog datuma, prepisanom od notara, kapetan dopunjuje zakladu određujući da mu, uz već navedeno, svi redovnici na godišnjicama preminuća služe misu te da na oltaru Triju Kraljeva gori vječno svjetlo. Taj je oltar, kako izričito zapisuje Protocollum conventus, potom postao oltarom Krunice (apud altare SS. Trium Regum modo S. Rosarii). Zbog te dopune misne

\footnotetext{
DEKOVIĆ 2011: 307-308.
}

22 Godine 1704. austrijski augustinski provincijal Josip Achinger i njegov tajnik Cezarije Posch, u vrijeme riječkoga priora Maksencija Pilepića, sastavili su njegov prvi dio do 62. stranice, a drugi dio od 63. do 221. stranice nastao je tijekom 18. stoljeća drugim rukama.

23 Protocollum conventus, N. 22, pag. 5.

24 DARI, HR-DARI-250, kut. 1, Protocollum conventus, N. 6, ovaj list nije paginiran [pag. 2]. Prijepis na njemačkom jeziku iz 1528. nalazi se u: Isto, kut. 6, skupina AA. Prepoznajemo Cimiottijev rukopis na prijepisu uspostave Fraynove misne zaklade sačuvane u Državnom arhivu u Rijeci, pri čemu nam daje vijesti o rodbinskoj vezi dvojice kapetana. 
zaklade, prije spomenutim augustinskim selištima (huebae) dodaje se i Lisac, selo s hrvatske strane današnje granice republika Hrvatske i Slovenije. ${ }^{25}$

Dana 31. listopada 1452. Ivan Čehovar (Cechovar) osniva misnu zakladu na oltaru sv. Nikole augustinske crkve sv. Jeronima dajući 4 selišta (mansos ili huebae) koja posjeduje u slovenskim mjestima ( 2 u Knežaku i 2 u Baču). S obzirom na to da je izvorni spis napisan na njemačkoj gotici, do danas sačuvan u Državnom arhivu u Rijeci, redovito se prenosilo ime u germanskoj verziji Hanne von Czekaren. ${ }^{26}$ Taj građanin Rijeke plemićkoga statusa polovicu zarade s njegova mlina u riječkom distriktu daje za vječno svjetlo na istom oltaru sv. Nikole. Prema toj su zakladi augustinci bili obavezni služiti 4 godišnje mise s vigilijom na kvaterne, dakle 4 puta godišnje. ${ }^{27}$

Dana 11. veljače 1466. uspostavio je Wolfgang de Walsee misnu zakladu za služenje triju tjednih misa kod augustinaca (jednu na čast sv. Stjepana, drugu sv. Antuna i treću sv. Kvirina), plaćajući legat iznosom od 9 maraka iz godišnje riječke carine i 15 libara voska, u naturi ili novcu. Godine 1472. Fridrik III. diplomom potvrđuje Wolfgangovu misnu zakladu. ${ }^{28}$ Vrelo Protocollum conventus, na temelju prijepisa notara iz 1521., Fridrikovu potvrdu smješta u 1472., donoseći prijepis uspostave misne zaklade, kao i Fridrihovu potvrdu. ${ }^{29}$ Potvrdu da augustinci i

25 DARI, HR-DARI-250, kut. 1, Protocollum conventus, N. 7, pag. 2.

26 Sastavljač augustinskog Protokola ispravno spominje Ivana Cechovara (Čehovar). Protocollum conventus, N. 9, pag. 3. Gigante navodi i datum od 6. veljače 1452., dok je točan datum zadnji dan oktobra, dakle 31. listopada. Gigante ni ostali ne navode ni sve ostale odredbe iz oporuke koje su važne za samostan. Usp. HERLJEVIĆ 1967-1969: 449.

27 Naknadno je dopisano u Protocollum kako su spomenute 4 huebae pod jurisdikcijom slovenskog Prema, a za mlin upućuje se na 1523. godinu, tj. na daljnju njegovu sudbinu. Prijepis je 1521. sastavio bilježnik. DARI, HR-DARI-250, kut. 2, pergamene, br. 4. Analitički inventar Državnog arhiva u Rijeci opisuje spis kao pergamenu na njemačkom jeziku pisanu goticom, bez potpisa pisara, malo oštećenu od vlage, veličine 18 x $30 \mathrm{~cm}$. Inventar Državnog arhiva u Rijeci također donosi Giganteovu pogrešnu germansku verziju imena spomenutoga građanina. Spis je prepisan u: ÖUW, II 351.241, Diplomatarium, CIIIr-CVIIv (106r-110v). Sažetak je u: DARI, HR-DARI-250, kut. 1, Protocollum conventus, N. 9, pag. 3; Usp. GIGANTE 1910: 17, 43. Godine 1910., kada je napisao članak, Gigante se nije koristio Protokolom koji se tada nije ni nalazio u Rijeci. Usp. HERLJEVIĆ 1967-1969: 449.

28 Prijepis iz 1521. Pergamena se čuva u Državnom arhivu u Rijeci, veličine 30,5 x $19 \mathrm{~cm}$, na njemačkom je jeziku i pisana goticom, s oštećenjem na rubu visećeg pečata. DARI, HR-DARI-250, kut. 2, br. 7. Prepoznajemo Cimiottijev rukopis na marginama prijepisa s regestom isprave. Isti arhiv ima prijepis obične izjave na njemačkom jeziku priora augustinskog samostana o zakladnim misama ustanovljenim po Wolfgangu Walseeu. DARI, HR-DARI-250, kut. 6, spisi AA, br. 2. Usp. HERLJEVIĆ 1967-1969: 450.

29 DARI, HR-DARI-250, kut. 6, spisi AA. Prepoznajemo Cimiottijev rukopis na marginama prijepisa sa sažetkom isprave. Vidi i: Protocollum conventus, N. 6-7, pag. 2. Usp. Protocollum conventus, N. 14, pag. 4; GIGANTE 1910: 41. Kobler o tome piše spominjući osam godina stariji spis iz 1474., u ponedjeljak nakon Uznesenja Marijina, kada car Fridrik III. određuje provedbu akta kojim je pokojni Wolfgang 1466. uspostavio misnu zakladu. Usp. KOBLER III 1896: 251. 
nakon nekoliko stoljeća služe mise za Walseeovca nalazimo u njihovu popisu misa iz 18. stoljeća. ${ }^{30}$

\section{Nepoznati augustinski hospital sv. Andrije}

Samostanski kartular Diplomatarium, sačuvan u Sveučilišnoj knjižnici u Beču, donosi vrlo vrijedan podatak o uspostavi hospitala u 15. stoljeću u Rijeci. ${ }^{31}$ Petar Glavinić u oporuci od 19. rujna 1479. ostavlja, među ostalim, tri vinograda koje posjeduje na riječkoj Kozali, pored ostataka starog rimskog zida, od kojih jedan treba poslužiti za izgradnju hospitala koji želi podići uz crkvu sv. Andrije u korist siromaha i dobro svoje duše (dimisit et ordinavit idem testator tres vinee... in contrata Coxalla iuxta antiquum murum sint \& etsi debeant hospitalis sancti Andreae quem edificare debet iuxta ecclesiam s. Andreae in argumento pauperum pro anima sua). ${ }^{32}$

Crkva sv. Andrije bila je jedno od augustinskih dobara. Nalazila se extra muros, na području današnje Ulice Erazma Barčića, sve do 1876., kada je srušena zbog izgradnje zgrade. ${ }^{33}$ Prema njoj, to je područje prozvano Andrejšćicom, a spominje se u nizu dobara samostana potvrđenih poveljom Reinprechta Walsea 1429. godine.

Hospital je doista izgrađen jer u inventaru dobara samostana sv. Jeronima, sačinjenom 23. travnja 1515. i prepisanom u Protocollum conventus, doznajemo da, među ostalim dobrima, uz crkvu sv. Andrije početkom 16. stoljeća augustinci posjeduju kuću hospitala (domus hospitalis) s pripadajućim zemljištem. ${ }^{34}$ To znači da je prije spomenuta oporučiteljeva želja iz 1479. da se podigne hospital uistinu ostvarena, iako ne znamo točnu godinu kada je realizirana. Nema nikakve sumnje da se radilo o hospitalu u vlasništvu augustinaca jer se nalazio na Andrejšćici, koja je samostansko vlasništvo i izričito se navodi u popisu dobara redovničke zajednice.

30 Catalogus missarum seu reductio noviter 1784 facta a reverendo patre Fanelo jest bilježnica od 10 listova s popisom misa sastavljenog nakon reduciranja misnih obveza, nekoliko godina prije ukinuća zajednice. DARI, HR-DARI-250, kut. 1.

31 Hospital je utočište za siromašne i marginalizirane, a u njemu prepoznajemo početke zdravstvene skrbi. U ranom srednjem vijeku crkve i samostani brinuli su se o bolesnicima, hodočasnicima i putnicima. U tim ustanovama, tvrdili su pravila i konstitucije, služi se samome Kristu. S vremenom sve veća financijska sposobnost građanstva potiče hospital da se počinje brinuti o bolesnicima. U razvijenom srednjem vijeku dolazi do komunalizacije hospitala, bilo da je bila riječ o svjetovnoj ili vjerskoj zadužbini.

32 Hospital se spominje u ÖUB, Diplomatarium, Xr. Ovjereni prijepis cijele Glavinićeve oporuke nalazi se u Diplomatarium, VIIIIv-XIv (12v-14v). Izvornu oporuku ovjerio je Andrija Raviza, javni bilježnik i kancelar riječki, građanin Trsta. Ovjereni je prijepis u Diplomatarium unio javni bilježnik i kancelar riječki Just Raviza, sin Andrijin, građanin Trsta. Usp. Protocollum conventus, N. 21, pag. 5. protokolom, zagubljenim izvorom. Usp. MEDVED 2018: 14, 16-18. 
Sredinom 16. stoljeća hospital još djeluje jer se spominje u jednoj ovjerenoj oporuci. Naime, Ivana, udovica Dominika del Vescovo, oporukom od 24. prosinca 1549. određuje, među ostalim, da njezin brat, prior Ivan Primožić, dostavi dva pokrivača siromasima u hospitalu (duas copertas sive sclavinas pauperibus hospitalis). ${ }^{35}$ Iz augustinskoga vrela Protocollum conventus doznajemo da je hospital postojao i 1621. godine. Naime, ugovor od 4. siječnja 1621. o najmu vrta Bartulu Benuliću, do treće generacije, u opisu lokacije vrta spominje da se nalazi ispred crkve sv. Andrije, da graniči s jedne strane s javnim putom, s druge strane s dobrom Katarine Kačić, s treće s kućom hospitala (domus hospitalis) i s četvrte s javnim putom. ${ }^{36}$ Početkom 18 . stoljeća zgrada pored crkve sv. Andrije još se uvijek naziva kućom hospitala. Naime, u vijesti od 21. veljače 1705., koju na talijanskom jeziku prenosi Protocollum conventus, spominje se da je augustinska zajednica dobro na Andrejšćici vratila obitelji Benulić, nakon što joj je ono bilo oduzeto zbog neplaćanja godišnjega najma, pri čemu spominje da ono graniči s „kućom zvanom hospital“ (casa detta dell'Ospitale). ${ }^{37}$ Smatramo da korištenje takvom formulacijom znači da zgrada 1705. više nije bila u službi hospitala.

Podatak o augustinskom hospitalu pri crkvi sv. Andrije do sada nije bio poznat. Uspostavljen nakon 1479., djelovao je zasigurno tijekom 16. stoljeća, ali nismo u stanju odrediti godinu njegova zatvaranja, koje se vjerojatno dogodilo sredinom ili u drugoj polovini 17. stoljeća. Znatno poznatiji bio je riječki hospital Duha Svetoga, otvoren u drugoj polovini 16. stoljeća, nadomak župne i zborne crkve Uznesenja Marijina. ${ }^{38}$

\section{Darovnica Baltazara De Dura}

Dana 13. srpnja 1484. riječki kapetan Baltazar De Dur daje samostanu kuću Grisani ${ }^{39}$ pored gradske lože za koju se augustinci obvezuju na slavljenje liturgije za njegovu pokojnu suprugu Katarinu, svakog petka na oltaru sv. Sebastijana i Fabijana u augustinskoj kapeli Presvetog Trojstva. K tome, ugovor određuje i odrješenje koje se treba davati na njezinu grobu, kao i misu svake godine na dan njezine smrti, tj. sv. Emerencijane (23. siječnja). Na to bogoslužje, određuje ugovor, trebaju se pozivati svi svećenici koji se nalaze na prostoru grada, odnosno 6 ili 8 kanonika, kojima augustinski prior treba platiti 6 solada. Određuje se i obveza paljenja svijeće na spomenutu oltaru, kao i služenje mise za suca Grisanija, kome

\footnotetext{
35 DARI, HR-DARI-250, kut. 1, Protocollum conventus, N. 100, pag. 22. Pravni akt donosi i ÖUB, Diplomatarium, LXIIIr-LXVv (66r-68v).

36 Isto, kut. 1, Protocollum conventus, N. 201, pag. 44.

37 Isto, kut. 1, Protocollum, pag. 83.

38 KOBLER III 1896: 57-62.

39 Kukuljević je naziva Gresani. KUKULJEVIĆ 1891: 205.
} 
je spomenuta kuća nekoć pripadala. De Dur je u darovnici odredio osobe koje će nadgledati primjenu uvjeta darovnice. Precizira se da riječki kapetani, ako kuća bude u lošem stanju, imaju ovlast dobro dati u najam i od dobivena iznosa izvršiti popravke. U tom slučaju osigurano je da iz iznosa najma trećinu dobivaju redovnici za vlastite potrebe. Na kraju darovnice De Dur poklanja augustincima jedan liturgijski parament zelene boje i jedan misal. ${ }^{40}$ Kamena ploča s De Durovom darovnicom prvotno se nalazila u kapeli Presvetog Trojstva, a danas stoji na ulazu u samostan. Tu će kuću samostan 1532. ustupiti gradskim vlastima na ime oslobađanja od trošarine na vino iz augustinskih vinograda. ${ }^{41}$

\section{Unutar samostanskih zidova sv. Jeronima \\ Riječki augustinci - biskupi u 15. stoljeću}

Pavao - augustinski prior i nesuđeni pićanski biskup

Augustinski prior Rijeke Pavao izabran je 1417. godine za pićanskog biskupa, ali ga Sveta Stolica nije potvrdila. Problem je bio u međusobnim odnosima austrijske i papinske vlasti u vremenu u kojem suprotstavljanja u postupku imenovanja biskupa imaju više političko-svjetovne negoli vjerske razloge. ${ }^{42}$ Pavao, riječki augustinski prior, 12. veljače 1417. daje svečano obećanje prigodom imenovanja za pićanskog biskupa, nakon smrti prethodnika Ivana Stanossija. ${ }^{43}$ No, nikad nije preuzeo službu ostajući samo episcopus electus, zbog čega ne ulazi u kronotaksu pićanskih biskupa. ${ }^{44}$

$\overline{40}$ Neovjereni prijepis na latinskom jeziku sačuvan je u Državnom arhivu u Rijeci. DARI, HRDARI-250, kut. 6, skupina AA, skupina A. Protocollum conventus donosi sažetak toga ugovora, N. 20, pag. 5. Usp. KUKULJEVIĆ 1891: 205-206.

41 Protocollum conventus spominje kako se ta odredba treba odnositi na vinograde u Dubašnici (ibidem in Dubasniza sibi plures vineas compareret), gdje su riječki augustinci, izričito se kaže, kupili više vinograda (N. 63, pag. 14). K tome, dobivaju oslobađanje od desetogodišnje trošarine na stoku. Dogovor s gradom stupa na snagu deset godina kasnije, 1542. Prijepis isprave riječkog notara Dominika Ravize iz godine 1542., kojim augustinski samostan kuću ustupa riječkom municipiju. DARI, HR-DARI-250, kut. 6, skupina B, 2. Usp. ÖUB, Diplomatarium, XXIIIIr-XXVIv (28r-29v). Ovjerena je Ravizova isprava u Diplomatarium. Usp. HERLJEVIĆ 1967-1969: 452.

42 BATELJA 2007: 126. Već spomenuti prijepis, upisan u Diplomatarium, prema kojem prior augustinskog samostana, Ivan, 19. listopada 1418. daje u najam Petru Lambuthu iz Rijeke samostansko zemljište, a kao svjedoka spominje augustinca Pavla, izabranog pićanskog biskupa. ÖUB, Diplomatarium, VIv-VIIv (9v-10v). Diplomatarium nosi višestruko numeriranu paginaciju (rimskim i arapskim brojevima). Za povijest riječkog augustinskog samostana važna je rimska Biblioteca Angelica jer čuva jedan od rukopisa važan riječkim redovnicima: Alphabetum fratris Felicis Milensii de nonnulis teutoniae, sarmatiaque citerioris monachis et monasteriis ordinis eremitarum sancti Augustini. U njemu se fra Pavao također spominje u vezi sa zemljištem na Cecilinovu. Biblioteca Angelica, Roma, Codice 148, 17v.

43 KOBLER III 1896: 243; KUNZELMANN 1974: 338.

44 ORBANIĆ 2002: 21-22. 
Marko Riječanin - augustinski provincijal i biskup u službi Matijaša Korvina

Najpoznatija osoba riječkog augustinskog samostana iz 15. stoljeća bio je Marko Riječanin, biskup u Senju (1461. - 1463.) i potom u Kninu. ${ }^{45}$ Postao je provincijalom Bavarske augustinske provincije, a odlikovale su ga intelektualne kvalitete, uzevši u obzir da ga je kralj Matijaš Korvin koristio za važne diplomatske misije. U ime kralja u više je navrata odlazio u Rim kako bi Svetu Stolicu informirao o prilikama u Bosni i pokrenuo organiziranje vojne za obranu Europe od Turaka. U Rimu je Marko uspio u zagovaranju kardinalskog grimiza za kaločkog nadbiskupa Stjepana. Nalazimo ga i u diplomatskim misijama u Veneciji radi organiziranja obrane od osmanske vlasti. Vrijeme je to pontifikata pape Pija II., za kojega znamo da je bio angažiran u obrani kršćanske Europe. Preminuo je 1467. ili $1468 .{ }^{46}$

Božo Nikolić nije bio modruški biskup

Povjesničar Torcoletti, pozivajući se na riječkog svećenika i povjesničara Josipa Poglajena, spominje da je 1499. godine Riječanin Božo Nikolić izabran za modruškog biskupa. ${ }^{47} \mathrm{Na}$ temelju točne premise da se u to vrijeme među redovnicima mogu naći obrazovaniji pojedinci negoli među svjetovnim klerom, Torcoletti pogrešno zaključuje da je spomenuti Nikolić bio augustinac, dakle pripadnik riječkog Reda sv. Jeronima. ${ }^{48}$

\section{Opadanje redovničke stege u 15 . stoljeću}

Navedeni primjeri biskupâ iz redova riječkih augustinaca svjedoče o zapaženim pojedincima unutar zajednice sv. Jeronima 15. stoljeća. No čini se da je nakon uzleta u prethodnom stoljeću, razina redovničkog života doživljavala krizu jer je druga polovina 15. stoljeća vrijeme opadanja stege u riječkih augustinaca. ${ }^{49}$ Višestruke su mjere koje, radi poboljšanja discipline i boljeg obdržavanja pravila, augustinski general Reda iz Rima i bavarski provincijal iz Münchena pokušavaju provesti u Rijeci. S tom svrhom pišu dopise riječkim priorima i šalju im svoje vizitatore. Godine 1477. general Reda Ambrozije von Cori radi reforme samostana u Rijeku šalje vizitatora Petra, lektora iz koruškog distrikta. To doznajemo iz

\footnotetext{
45 U prošlosti bilo je različitih stavova oko njegova redovničkog identiteta. Usp. BOGOVIĆ 2003: 50. Poznati augustinski autor HERRERA(II 1644: 76-77) spominje Marka Riječanina: „Marcus de Terra Fluminis, sacrae Theologiae Lector“. Usp. REGALATI 1928: 96.

46 TORCOLETTI 1944: 17; REGALATI 1928: 96-106.

47 TORCOLETTI 1944: 17.

48 M. Bogović taj podatak odbacuje objašnjavajući da se temelji na „bilješci nesigurna porijekla“, zbog čega je od premalog značenja da „bismo u nj povjerovali“. BOGOVIĆ 2002: 55.

49 KUNZELMANN 1972: 21.
} 
važnog kodeksa za povijest bavarskih augustinaca - kojima do druge polovine 16 . stoljeća pripadaju i riječki redovnici - sačuvanog u Bavarskoj državnoj knjižnici u Münchenu. ${ }^{50}$ Taj Codex latinus monacensis zapisuje za 1477. godinu sljedeću vijest: Fecimus visitatorem prioris terrae Fluminis vicario nostro Petro, lectori districtus Carinthiae. ${ }^{51}$ Isti je general Ambrozije 1482. riječkim augustincima naredio da provedu reformu. On je najprije bavarskom provincijalu Andriji iz Brna naložio da reformira sve svoje samostane, ali je zatim dodao i jednu vlastitu naredbu za riječki samostan. Oštrim tonom i pod prijetnjom kazne, 1. lipnja iste godine zapovjedio je riječkim augustincima da se reformiraju: Commissimus Andreae de Bruna provinciali, quod reformet omnes conventus provinciae ad regularem vitam. 1 Iunii mandavimus conventui terrae Fluminis, ut se reformet sub poena rebellionis. ${ }^{52}$ Međutim, 3. listopada 1489. pisao je general Anselmo von Montefalco bavarskom provincijalu blagim tonom da ne može samostan u Rijeci previše opteretiti prikupljanjem doprinosa, što praktički znači popuštanje pred zahtjevima riječkih redovnika. ${ }^{53}$

\section{Izgradnja kapela}

Kapela Presvetoga Trojstva, današnja sakristija crkve sv. Jeronima, sagrađena je sredinom 15. stoljeća. Ovu gotičku kapelu utemeljio je Martin Raunacher. Njegov se grob od crvenog mramora prvotno nalazio u središtu kapele, mjestu koje je bilo pridržano utemeljitelju ili patronu. Kvaliteta te grobne ploče razlog je njezina višekratnog spominjanja u javnosti, iako još uvijek nedostaje stručna publikacija koja bi je vrednovala. ${ }^{4}$

50 Riječ je o zapisu iz registra generalnog priora u Rimu koji je nastao između 1728. i 1730. Poznat je pod naslovom Codex latinus monacensis, a autor mu je najvjerojatnije Angelus Höggmayr. Bayerische Staatsbibliothek, München (dalje: BSB), Codex latinus monacensis 8423. Compendium seu notata ex registris vel commentariis generalibus archivi generalis, item ex bibliotheca nostra Romana Angelica ac ex aliis authenticis documentis excerpta tum per me tum per ammanuenses praecipue quae concernunt $S$. nostri ordinis provincias Germaniae, Poloniae, Hungariae etc.

BSB, Codex latinus monacensis 8423, pag. 333.

Isto.

„1489. 3. Oct (...) Eique mandavimus, ut non aggravet in collectis conventum Fluminensem propter bella Ungariae.“ Isto, pag. 335.

54 Ova plemićka obitelj javlja se u izvorima u prvoj polovini 14. stoljeća. Jedan je član obitelji tada sagradio utvrdu kojoj je dao naziv Raunach (Ravne) kod Pivke, od čega vjerojatno potječe i ime Raunach(er). Gospoštija Raunach nalazila se u blizini Prema i Svetoga Petra na Krasu. Raunacheri su kraj svoje utvrde 1471. izgradili utvrdu Šilentabor (Tabor nad Zagorjem), a oko 1664. dobili titulu baruna Siller-Tabora i Momjana. Željko Bistrović, viši konzervator iz Konzervatorskog odjela u Rijeci, jedan je od rijetkih autora koji su u novije vrijeme duboko zašli u proučavanje prošlosti riječkog augustinskog kompleksa, bez obzira na to što je još izostalo publiciranje njegovih radova. On upućuje na krašku provenijenciju Raunacherovih, pri čemu 
Vjerojatno se koncem 15. stoljeća počinje graditi kapela Majke Milosti (Mater Gratiae) augustinskoga samostana. ${ }^{55}$ Gradnja je završena tek u prvoj polovici 16. stoljeća, s obzirom na 1515. godinu, kada se formulira obveza zavjetne mise, prepisana u Protocollum. ${ }^{56}$ Budući da je u drugoj polovini 16. stoljeća kapelu preuzela bratovština Bezgrešnog začeća BDM, i kapela mijenja titulu, kao i glavni oltar, pa je do danas poznajemo pod nazivom „od Bezgrešnog Začeća“. Gradski kapetan Gašpar Rauber u drugoj polovini 15. stoljeća vodi gradnju. ${ }^{57}$ Nakon stanke, uzrokovane mletačkim haranjem gradom 1509. i 1511., s radovima se nastavlja nakon toga. Sačuvana je grobna ploča Gašparova brata Nikole Raubera, preminulog $1482 . .^{58}$

Sačuvana vrela, samostanski kartular Diplomatarium, kao i Protocollum conventus, svjedoče o intenzivnoj poslovnoj djelatnosti riječkih augustinaca u prvoj polovici osamdesetih godina 15. stoljeća. Legitimno je postaviti hipotezu da je riječkim augustincima tada trebalo financijskih sredstava kako bi platili radove $\mathrm{u}$ samostanu. U dosadašnju kronotaksu priora augustinskog samostana sv. Jeronima, koja spominje priore Petra iz 1474. i Gašpara iz 1487. godine, treba umetnuti ime priora Antuna iz Velikovca. Njega Diplomatarium spominje kao priora 1483. godine, i to s pridjevom zaslužan. ${ }^{59}$ Možda je upravo on vezan za neke od radova u klaustru, poput fresaka na ulazu kapele Bezgrešne, a na kojima je na dnu vidljiv natpis de Fiume.

\section{O samostanskom arhivu}

Riječki historičar Ljudevit Josip Cimiotti-Steinberg spominje da je augustinski samostan, uz dokumente vezane uz samostan, čuvao i spise gradskoga arhiva. Pozivajući se na Vincenta Marcellina Maura, posljednjega riječkog augustinca preminulog 11. prosinca 1828. u Beču (u rodu s Cimiottijem po strani brata njegove majke), navodi redovnikovu knjižnu ostavštinu i samu oporuku. U njoj je, preuzimajući podatke iz onoga što naziva „Liburnijskom kronikom“ koja se čuvala u arhivu, Mauro izričito ustvrdio kako je Cimiotti-Steinberg prenio da je

ukazuje da se kao upravna cjelina Kras ostvaruje upravo u 15. stoljeću pod Walseeovcima. Unutar te političke cjeline ulazi i grad Rijeka, zajedno s Kastvom, Klanom i Gotnikom. Neobjavljeni Bistrovićev članak „Raunacheri, povijest jedne plemićke obitelji s Krasa u 15. stoljeću“.

55 TORCOLETTI 1944: 42.

56 Zaklada Rauber upisana je u DARI, HR-DARI-250, kut. 1, Protocollum conventus, N. 33, pag. 8.

57 KOBLER 1896: 28-30.

58 Isto.

59 ÖUB, Diplomatarium, Vr-VIr (8r-v). Popis priora donosi KOBLER 1896: 96, a prenosi HERLJEVIĆ 1967-1969: 439. 
riječki sv. Jeronim, osim vlastita samostanskog arhiva, čuvao i spise gradskoga arhiva. Oba su uništili Mleci $1509 .{ }^{60}$

Među ostalim, samostan sv. Jeronima imao je i urbar iz 1431. godine. Naime, postavši priorom 1. srpnja 1523., Ivan Primožić daje nalog notaru Ivanu Barberiću da izradi popis inventara riječkog augustinskog samostana. Protocollum conventus, u zapisu o tome da prior Primožić u prvoj polovini 16. stoljeća nalaže izradu inventara, donosi i vijest da je tada, u prvoj polovini 16. stoljeća, još postojalo 6 listova starog urbara augustinskog samostana iz $1431 .{ }^{61}$

\section{Zaključak}

Život riječkog samostana augustinaca pustinjaka u 15. stoljeću započinje dovršetkom izgradnje samostana s crkvom sv. Jeronima (1408./1409.). Poteškoće u rekonstruiranju njihova života $u$ tome razdoblju proizlaze iz stradanja samostana u mletačkim napadima 1509., u kojima je, osim crkve i samostana, uništen i dio arhivske građe. No, i s građom koja nam je na raspolaganju - raspršena po svjetovnim i crkvenim arhivima Rijeke, Zagreba, Ljubljane, Beča, Budimpešte, Rima i Münchena - opravdano se može zaključiti kako je 15. stoljeće vrijeme učvršćenja riječkih redovnika u materijalnom pogledu. Reinprecht Walsee potvrdio je listinom iz 1429. dobra koja je Hugon Devinski, njegov djed po majčinoj liniji, udijelio augustincima sv. Jeronima.

Riječki redovnici u tome vremenu pripadaju velikoj Bavarskoj augustinskoj provinciji, unutar distrikta za područje Štajerske i Koruške. Druga polovina 15. stoljeća vrijeme je opadanja stege u obdržavanju redovničkog pravila, zbog čega središnje strukture reda u Rimu, kao i provincijalne u Münchenu, riječkim priorima šalju dopise i vizitatore sa svrhom reforme redovničkog života. Bez obzira na to, o kvaliteti redovnikâ koji su u tome stoljeću činili zajednicu sv. Jeronima svjedoči podatak o nekoliko biskupskih imenovanja iz redova riječkih augustinaca.

Ostala je do sada nepoznata vijest o uspostavi augustinskog hospitala pri crkvi sv. Andrije. Zahvaljujući pobožnoj oporuci riječkoga građanina Petra Glavinića iz 1479., augustinski hospital sv. Andrije djeluje tijekom 16. i u dijelu 17. stoljeća. U

60 Prenosimo zapis ostajući vjerni izvornom stilu talijanskog teksta, uključujući i greške: „Siccome poi nell'anno 1509 fu tutta la città di Fiume dalla flotta Veneta brugiata, e spolgiato esso convento Agostiniano sì del proprio che del civico archivio, così li fugitivi da Fiume religiosi Agostiniani dispergendosi in varie vicine parochie tunc temporis a loro sogiette (Cronicon Liburniae).“ Sveučilišna knjižnica u Rijeci. Rara, inkunabule i rukopisi, A.189. I. Cimiotti, Publico-politica Terrae Fluminis S. Viti adumbratio, 41. Vidi Maurovu oporuku u DARI, HRDARI-494, Kotarski sud Rijeka, PR-8, Ventilazione del padre Marcellino Vincenzo Mauro ex Agostino, kut. 315.

61 „Fragmentum urbarii conventus in pergamena sex foliorum de a. 1431.“, Protocollum conventus, N. 47, pag. 11. 
drugoj polovini 15. stoljeća počinje se graditi kapela Majke Milosti (Mater Gratiae) augustinskoga samostana, vezana uz obitelj Rauber. Sredinom 15. stoljeća Martin Raunacher gradi gotičku kapelu Presvetoga Trojstva, današnju sakristiju crkve sv. Jeronima. Najvažnije misne zaklade u povijesti samostana potječu iz razdoblja 15. stoljeća. Bilo je to vrijeme mirnoga života i učvršćenja zajednice pred kojom je tek slijedilo razdoblje najtežih iskušenja prve polovine 16. stoljeća, označeno mletačkim pustošenjem grada, kao i reformacijom koju je pokrenuo augustinac Martin Luther.

\section{Bibliografija}

\section{Izvori}

Bayerische Staatsbibliothek, München

Codex latinus monacensis 8423 . Compendium seu notata ex registris vel commentariis generalibus archivi generalis, item ex bibliotheca nostra Romana Angelica ac ex aliis authenticis documentis excerpta tum per me tum per ammanuenses praecipue quae concernunt S. nostri ordinis provincias Germaniae, Poloniae, Hungariae etc.

Biblioteca Angelica, Rim

Codice 148.

Codice 353.

Državni arhiv u Rijeci

HR-DARI-250, Samostan reda pustinjaka sv. Augustina u Rijeci, kut. 1-8.

HR-DARI-494, Kotarski sud Rijeka, PR-8, Ventilazione del padre Marcellino Vincenzo Mauro ex Agostino, kut. 315.

Nadbiskupijski arhiv u Rijeci

Zborni kaptol i Arhiđakon.

Österreichische Universitätsbibliothek, Wien

II 351.241. Diplomatarium monasterii sancti Hieronimi ordinis eremitarum sancti Augustini in terra Fluminis sancti Viti.

Sveučilišna knjižnica u Rijeci

Rara, inkunabule i rukopisi. Ljudevit Josip Cimiotti-Steimberg, Publico-politica Terrae Fluminis S. Viti adumbratio historice ac diplomatice illustrata.

\section{Literatura}

BATELJA, Juraj. 2007. Baština svetoga Augustina u Istri. Zagreb: Postulatura bl. Alojzija Stepinca.

BATELJA, Juraj. 2008. Augustinski samostan u Opatiji. U Opatijske crkvene obljetnice. Zbornik radova sa znanstvenog skupa održanog u Opatiji 17. i 18. studenoga 2006. 
godine, ur. Goran Crnković, 31-43. Opatija: Grad Opatija, Rezidencija DI u Opatiji, Župa sv. Jakova.

BOTICA, Ivan, Tomislav GALOVIĆ. 2014. Glagoljična pismenost srednjovjekovne Dubašnice. U Zbornik radova s prve medievističke radionice u Rijeci, ur. Kosana Jovanović, Suzana Miljan, 55-71. Rijeka: Filozofski fakultet sveučilišta u Rijeci.

BOGOVIĆ, Mile. 2003. Senjsko-modruška ili Krbavska biskupija. Izvješća biskupa Svetoj Stolici (1602. - 1919.). Zagreb: Hrvatski državni arhiv, Kršćanska sadašnjost.

BRADANOVIĆ, Marijan. 2017. Nekoliko primjera baštine kasnoga srednjovjekovlja Rijeke i Kvarnera. Ars Adriatica 7: 113-128.

BRADANOVIĆ, Marijan. 2017. Rijeka i Trsat u srednjem vijeku. Split: Muzej hrvatskih arheoloških spomenika [Kulturno-povijesni vodič, sv. 34].

BRAUT, Ivan. 2015. Nadgrobne ploče iz nekadašnjeg augustinskog samostana u Rijeci. Sedam stoljeća augustinskog samostana u Rijeci. Znanstveni skup s međunarodnim sudjelovanjem, 22. - 24. listopada 2015. Knjiga sažetaka. Rijeka: Filozofski fakultet Sveučilišta u Rijeci.

BUDAK, Neven. 2007. Hrvatska i Slavonija u ranome novom vijeku. Zagreb: Barbat, Leykam international.

DEKOVIĆ, Darko. 2003. Hrvatskoglagoljični prijevodi u Diplomatariumu augustinskoga samostana u Rijeci. Dometi 13: 29-70.

DEKOVIĆ, Darko. 2006. Trojezičje Diplomatariuma augustinskoga samostana u Rijeci. U Međunarodni znanstveni skup „Latinitet u Europi s posebnim osvrtom na hrvatski latinitet nekad i danas ", Rijeka - otok Krk, 20. - 23. listopada 2004. Zbornik radova, ur. Darko Deković, 304-336. Rijeka: Matica hrvatska - Ogranak u Rijeci [Niz Zbornici 3].

DEKOVIĆ, Darko. 2011. Istraživanja o riječkome glagoljaškome krugu. Zagreb: Matica hrvatska.

DEPOLI, Guido. 1912. Aggiunta all'inventario dell'archivio degli Agostiniani. Bullettino della deputazione fiumana di storia patria 2: 131-133.

DEPOLI, Guido. 1929. La provincia del Carnaro. Saggio geografico. Fiume: Società di studi fiumani.

DOBRONIĆ, Lelja. 1987. Augustinci u srednjovjekovnoj Slavoniji i Hrvatskoj. Croatica Christiana Periodica 11: 1-25.

DOBRONIĆ, Lelja. 1996. Augustinci na otoku Hvaru. Građa i prilozi za povijest Dalmacije 12: 57-63.

GALOVIĆ, Tomislav. 2016. Historical Circumstances of the Appearance of Medieval Cartularies in Croatia. Иницијал. Часопис за средњовековне студије / Initial. A Review of Medieval Studies 4: 73-95.

GALOVIĆ, Tomislav. 2018. Libellus Policorion/Rogovski kartular, sv. I.: Kodikološki opis, paleografska analiza, faksimil. Zadar: Državni arhiv u Zadru.

GIGANTE, Silvino. 1910. Gli Agostiniani del convento di S. Girolamo. Bullettino della Deputazione fumana di storia patria 1: 16-96.

GROSSI, Vittorino, Luis MARÍN, Gino CIOLINI. 1993. Gli agostiniani. Radici, storia, prospettive. Palermo: Augustinus. 
HERLJEVIĆ, Antun. 1967.-1969. Arhiv augustinskog samostana u Rijeci. Jadranski zbornik VII: 435-459.

HERRERA, Tomás de. 1644. Alphabetum Augustinianum, in quo praeclara eremitici Ordinis germina, virorumque, et faeminiarum domicilia recensentur, vol. I-II. Matriti: Typis Gregorii Rodriguez.

KLEN, Danilo. 1998. Povijest Rijeke. Rijeka: Skupština općine, Izdavački centar Rijeka.

KOBLER, Giovanni. 1896. Memorie per la storia della liburnica città di Fiume, sv. I.-III. Fiume: Stab. Tipo-lit. Fiumano di E. Mohovich.

KOSANOVIĆ, Ozren. 2018. Inventar pokretnih dobara augustinskog samostana sv. Jeronima u Rijeci iz 1523. godine. Problemi sjevernog Jadrana 17: 23-33.

KUKULJEVIĆ SAKCINSKI, Ivan. 1891. Nadpisi sredovječni i novovjeki na crkvah, javnih i privatnih sgradah i $t$. d. u Hrvatskoj i Slavoniji. Zagreb: Knjižara Jugoslavenske akademije, Knjižara Dioničke tiskare.

KUNZELMANN, Adalbero. 1972. Geschichte der deutschen Augustiner-Eremiten, vol. III: Die bayerische Provinz bis zum Ende des Mittelalters. Würzburg: Augustinus-Verlag.

KUNZELMANN, Adalbero. 1974. Geschichte der deutschen Augustiner-Eremiten, vol. V: Die sächsisch-thüringische Provinz und die sächsische Reformkonrgregation bis zum Untergang der beiden. Würzburg: Augustinus-Verlag.

MARDEŠIĆ, Andrija Vojko. 2005. Augustinci u Visu. Hrvatska zora: glasilo Ogranka Matice hrvatske Vis 15: 7-8.

MATEJČIĆ, Radmila. 1988. Kako čitati grad. Rijeka jučer, danas. Rijeka: Izdavački centar Rijeka.

MEDVED, Marko. 2015.-2016. Augustinci pustinjaci u Senju. Senjski zbornik. Prilozi za geografiju, etnologiju, gospodarstvo, povijest i kulturu 41-42: 443-452.

MEDVED, Marko. 2018. Dva nepoznata inventara riječkoga augustinskog samostana sv. Jeronima iz 16. st. Problemi sjevernog Jadrana 17: 9-21.

ORBANIĆ, Elvis. 2002. Katedra svetog Nicefora. Povijesna skica Pićanske biskupije. Pazin: Josip Turčinović.

REGALATI, Giovanni. 1928. Missioni diplomatiche del vescovo di Knin, Marco da Fiume. Fiume. Rivista di studi fiumani VI: 96-106.

RIGLER, Jakob. 1968. Jezikovnokulturna orientacija Štajercev v starejših obdobjih. U Svet med Muro in Dravo. Ob 100-letnici 1. slovenskega tabora v Ljutomeru, ur. Viktor Vrbnjak, 661-681. Maribor: Obzorja.

ROSNAK, Martin, Xystus SCHIER. 1776. De Monasteriis provinciae Austriae et Hungariae ordinis fratrum eremitarum sancti patris Augustini succincta notitia, in usum duntaxat juniorum ejusdem Provinciae alumnorum obiter conscripta. Viennae: Litteris Schulzianis.

ŠURMIN, Đuro. 1898. Hrvatski spomenici, sv. I. Zagreb: Jugoslavenska akademija znanosti i umjetnosti.

ZANINOVIĆ RUMORA, Marija. 1997. Inventar samostana sv. Nikole u Hvaru. Prilozi povijesti otoka Hvara 10: 172-184.

ZJAČIĆ, Mirko. 1955.-1956. Knjiga riječkog kancelara i notara Antona de Renno de Mutina (1436-1461) I. Vjesnik historijskih arhiva u Rijeci i Pazinu 3: 5-340. 


\section{The Augustinian Convent of St. Jerome in Rijeka in the $15^{\text {th }}$ century}

The Order of Saint Augustine was founded in 1244 by consolidating several eremitical groups in the Tuscany region that followed the Rule of St. Augustine, written by the Saint of Hippo in the $5^{\text {th }}$ century. In its establishment in its current form, it was shaped as a mendicant order, one of the four great orders which follow that way of life.

The Order of St. Augustine was in fact the first religious community in Rijeka. The monastery, founded by the Devin and Walsee families (the feudal lords of Rijeka), existed from the $14^{\text {th }}$ century until 1788 , when it was dissolved by Joseph II. The archives suffered two major disasters: in 1509, when the Venetians partially destroyed it, and in 1788, the year of its closure. The Augustinian archives remained partially in the State Archives in Rijeka, but the largest part of its precious fund was displaced.

Unfortunately the past of the Augustinian Convent of St. Jerome is mostly unknown. On the basis of almost unexplored sources in Croatia and overseas, the author reveals several facts about the Rijeka's Augustinian community in the $15^{\text {th }}$ century.

In the successful German branch of the Bavarian province, the history of the Order of St. Augustine in Rijeka in the $15^{\text {th }}$ century links the city and its region to Central Europe - specifically to Bavaria, Bohemia, Austria, Slovenia and Italy. The Augustinian community was an important factor in Rijeka's feudal society and the surrounding communities with mills, ovens, vineyards, orchards in Andrejšćica, Cecilinovo (Mlaka), Mihačeva Draga, Rečice, Klana, Kastav, Dubašnica (on the island of Krk), Lipa, Studena, and the Slovenian villages of Podgraje, Žabiče, Kuteževo and Trpčane. The paper includes important information concerning the existence of a hospital at the Andrejšćica location in Rijeka, established in the $15^{\text {th }}$ century, which was previously unknown. The most famous member of Augustinian community in the Middle Ages was Mark, a prior and bishop, who served in the diplomatic corps of Hungarian-Croatian King Matthias Corvinus. The Gothic Holy Trinity Chapel, currently a sacristy situated beside the eastern cloister, was constructed in 1450 by Rijeka's captain at the time, Raunacher.

Key words: Order of Hermits of St. Augustine, Church and Convent of St. Jerome in

Rijeka, Hospital of St. Andrew, Reinprecht Walsee

Ključne riječi: Rijeka, augustinci pustinjaci, crkva i samostan sv. Jeronima u Rijeci, hospital sv. Andrije, Reinprecht Walsee

Marko Medved

Teologija u Rijeci

Područni studij Katoličkog bogoslovnog fakulteta Sveučilišta u Zagrebu

Omladinska 14

HR-51000 Rijeka

marko.medved.rijeka@gmail.com 


\section{FILOZOFSKI FAKULTET SVEUČILIŠTA U ZAGREBU \\ ZAVOD ZA HRVATSKU POVIJEST \\ INSTITUTE OF CROATIAN HISTORY \\ INSTITUT FÜR KROATISCHE GESCHICHTE}

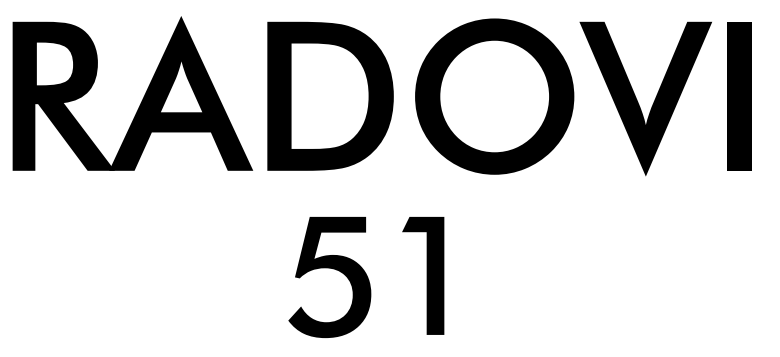

BROJ 2

ZAVOD ZA HRVATSKU POVIJEST

FILOZOFSKOGA FAKULTETA SVEUČILIŠTA U ZAGREBU

\section{FF press}

ZAGREB 2019. 


\title{
RADOVI ZAVODA ZA HRVATSKU POVIJEST FILOZOFSKOGA FAKULTETA SVEUČILIŠTA U ZAGREBU
}

\author{
Knjiga 51, broj 2
}

\author{
Izdavač / Publisher \\ Zavod za hrvatsku povijest \\ Filozofskoga fakulteta Sveučilišta u Zagrebu \\ FF-press \\ Za izdavača / For Publisher \\ Vesna Vlahović Štetić \\ Glavni urednik / Editor-in-Chief \\ Inga Vilogorac Brčić \\ Izvršni urednik / Executive Editor \\ Kornelija Jurin Starčević \\ Uredništvo / Editorial Board
}

Jasmina Osterman (stara povijest/ancient history), Trpimir Vedriš (srednji vijek/medieval history), Hrvoje Petrić (rani novi vijek/early modern history), Željko Holjevac (moderna povijest/ modern history), Tvrtko Jakovina (suvremena povijest/contemporary history), Silvija Pisk

(mikrohistorija i zavičajna povijest/microhistory and local history),

Zrinka Blažević (teorija i metodologija povijesti/theory and methodology of history)

Međunarodno uredničko vijeće / International Editorial Council

Denis Alimov (Sankt Peterburg), Živko Andrijašević (Nikšić), Csaba Békés (Budapest), Rajko

Bratož (Ljubljana), Svetlozar Eldarov (Sofija), Toni Filiposki (Skopje), Aleksandar Fotić

(Beograd), Vladan Gavrilović (Novi Sad), Alojz Ivanišević (Wien),

Egidio Ivetić (Padova), Husnija Kamberović (Sarajevo), Karl Kaser (Graz),

Irina Ognyanova (Sofija), Géza Pálffy (Budapest), Ioan-Aurel Pop (Cluj),

Nade Proeva (Skopje), Alexios Savvides (Kalamata), Vlada Stanković (Beograd),

Ludwig Steindorff (Kiel), Peter Štih (Ljubljana)

Izvršni urednik za tuzemnu i inozemnu razmjenu /

Executive Editor for Publications Exchange

Martin Previšić

Tajnik uredništva / Editorial Board Assistant

Dejan Zadro

Adresa uredništva/Editorial Board address

Zavod za hrvatsku povijest, Filozofski fakultet Zagreb, Ivana Lučića 3, HR-10 000, Zagreb Tel. ++385(0)1 6120191

Časopis izlazi jedanput godišnje / The Journal is published once a year

Časopis je u digitalnom obliku dostupan na / The Journal in digital form is accessible at Portal znanstvenih časopisa Republike Hrvatske „Hrčak“ http://hrcak.srce.hr/radovi-zhp

Financijska potpora za tisak časopisa / The Journal is published with the support by Ministarstvo znanosti, obrazovanja i športa Republike Hrvatske

Časopis je indeksiran u sljedećim bazama / The Journal is indexed in the following databases: Directory of Open Access Journals, EBSCO, SCOPUS, ERIH PLUS, Emerging Sources Citation Index - Web of Science 


\title{
Naslovna stranica / Title page by Marko Maraković
}

\section{Grafičko oblikovanje i računalni slog / Graphic design and layout Marko Maraković}

\author{
Lektura / Language editors \\ Samanta Paronić (hrvatski / Croatian) \\ Edward Bosnar (engleski / English)
}

Tisak / Printed by

Tiskara Zelina, Sv. Ivan Zelina

Naklada / Issued

200 primjeraka / 200 copies

Ilustracija na naslovnici

Muza Klio (Alexander S. Murray, Manual of Mythology, London 1898)

Časopis je u digitalnom obliku dostupan na Portalu znanstvenih časopisa Republike Hrvatske ,Hrčak“ http://hrcak.srce.hr/radovi-zhp

The Journal is accessible in digital form at the Hrcak - Portal of scientific journals of Croatia http://hrcak.srce.hr/radovi-zhp 